\title{
Simple bone cyst in a 7-year-old child
}

\author{
Cisto ósseo simples em criança de 7 anos
}

\author{
Heitor ALBERGONI DA SILVEIRA ${ }^{1}$ \\ Camila LOPES CARDOSO' \\ Mariane PEXE ${ }^{1}$ \\ Rafael ZETEHAKU ARAUJO' \\ Anthony BENITES CONDEZO ${ }^{1}$ \\ Marcos MARTINS CURI ${ }^{2}$
}

\begin{abstract}
The simple bone cyst, or traumatic bone cyst, solitary or idiopathic bone cavity is an intraosseous pseudocyst discovered through a panoramic radiographic examination. Commonly, the SBC is presented as an asymptomatic lesion, radiolucent, unilocular, without cortical expansion, with margins adorning vital tooth roots of the affected region. The literature has recommended that clinical and radiographic aspects of simple bone cyst are quite convincing as to diagnosis, so follow-up through clinical and radiographic examination has been suggested. This case illustrates an exuberant clinical case of simple bone cyst, which was presented as multilocular and expansive lesion in a 7-year-old patient. Surgical exploration was performed because her parents were anxious about the presumptive diagnosis of other more aggressive lesions. The diagnosis of SBC was confirmed. The case was monitored and, after three years, total bone remodeling of the affected area was observed. In conclusion, asymptomatic radiolucent lesions that suggest a strong presumptive diagnosis of a simple bone cyst can be clinically and radiographically monitored. However, clinical variations, as in the present clinical case, require confirmation of the diagnosis, which is performed through exploratory surgery. The establishment of the diagnosis affords the safest approach for both the professional and the patient.
\end{abstract}

Indexing terms: Bone cyst. Child. Differential diagnosis.

\section{RESUMO}

O cisto ósseo simples, ou cisto ósseo traumático, solitário ou cavidade óssea idiopática é um pseudocisto intra-ósseo descoberto através de um exame radiográfico panorâmico. Comumente, o cisto ósseo simples se apresenta como uma lesão assintomática, radiolúcida, unilocular, sem expansão de corticais, com margens festonando as raízes dentárias vitais da região afetada. A literatura tem recomendado que os aspectos clínicos e radiográficos do cisto ósseo simples são bastante convincentes do seu diagnóstico, portanto a proservação através de exame clínico e radiográfico tem sido sugerida. O presente caso ilustra um caso clínico de um grande cisto ósseo simples, o qual se apresentava multilocular e expansivo, numa criança de 7 anos. Diante da ansiedade dos pais e diagnóstico presuntivo de outras lesões mais agressivas, foi realizada a exploração cirúrgica, a qual confirmou o diagnóstico de cisto ósseo simples. O caso foi acompanhado e, após três anos, foi observada a total remodelação óssea da área afetada. Como conclusão, as lesões radiolúcidas assintomáticas que sugerirem um diagnóstico presuntivo muito indicativo de cisto ósseo simples, podem ser acompanhadas clínica e radiograficamente. Entretanto, as variações de apresentação clínica, como no presente caso clínico, requerem uma confirmação do diagnóstico, a qual é realizada através da exploração cirúrgica. O estabelecimento do diagnóstico torna a condução do caso mais segura para ambos o profissional e o paciente.

Termos de indexação: Cisto ósseo solitário. Criança. Diagnóstico diferencial.

\section{INTRODUCTION}

A simple bone cyst (SBC), also referred to as traumatic or solitary bone cyst, or idiopathic bone cavity, is considered an intraosseous pseudocyst devoid of epithelial lining, containing serosanguineous fluids or none at all1-4. The SBC is seen more in the second decade of life, the mandible being the region most frequently affected'. Radiographically, it appears radiolucent, unilocular or multilocular, almost always without cortical expansion, with the margins adorning the roots of the teeth in the affected region ${ }^{1-4}$. Clinically it is asymptomatic and its final diagnosis is obtained during exploratory surgery, when the surgeon confirms that the cavity is empty ${ }^{1-3}$. In terms of how this entity should be handled, there is little consensus in the literature, whether it should be by monitoring or through exploratory surgery ${ }^{1-5}$. The aim of the present case is to illustrate an atypical case of SBC which, given its large size and moderate bone expansion, was treated via exploratory surgery.

\footnotetext{
${ }^{1}$ Universidade do Sagrado Coração, Departamento de Cirurgia. Rua Irmã Arminda,10-50, Jardim Brasil, 17011-160, Bauru, SP, Brasil. Correspondência para / Correspondence to: CL CARDOSO.E-mail: <cardoso_lopes@yahoo.com.br>.

${ }^{2}$ Hospital Santa Catarina, Departamento de Oncologia. São Paulo, SP, Brasil.
} 


\section{CASE REPORT}

Caucasian, female patient aged 7, was referred to our team with a panoramic x-ray that revealed an asymptomatic, unilocular, radiolucent lesion in the anterior region and body of the left mandible (figure 1). According to her reported medical history, there was no associated causal factor, nor history of trauma in the region. Cone-beam computed tomography showed a large, multilocular, hypodense area in the affected region. The axial reconstructions revealed moderate cortical expansion (figures 2 and 3). The main diagnostic hypotheses were keratocystic odontogenic tumor (KOT) and SBC. Given the extent of the alteration and the anxiety of the parents, exploratory surgery of the altered area was scheduled in order to establish a definitive diagnosis. During the intraoperative phase, an empty cavity was found confirming the diagnosis of SBC (figure 4). After exploratory surgery, over the course of 3 years, the affected region was completely repaired, revealing the formation of a lamina dura and no alteration to the permanent erupted teeth, thus corroborating the literature with regard to prognosis (figure 5).

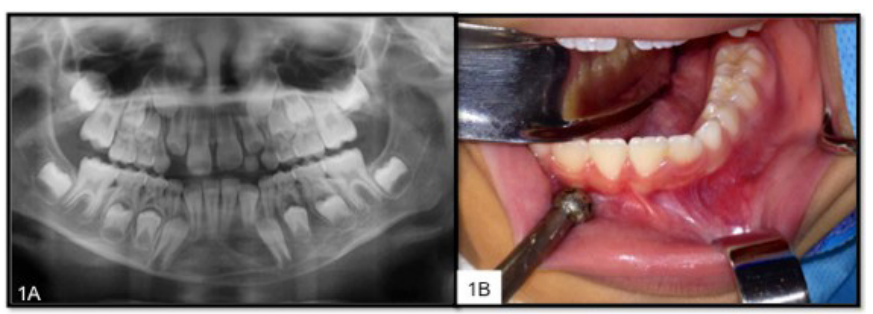

Figure 1. Initial appearance. A) Panoramic x-ray showing a well-circumscribed, unilocular, radiolucent region, from the region of the incisors to the left-side molars. The teeth presented no tooth resorption. B) Intraoral appearance, demonstrating normal mucosa lining the affected region, without bone expansion.

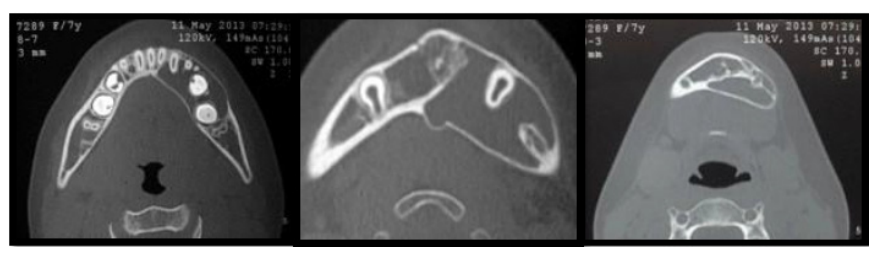

Figure 2. Axial reconstructions of the cone-beam computed tomography demonstrating a moderately expansive, multilocular, hypodense area when observed closer to the lower edge of the mandible.

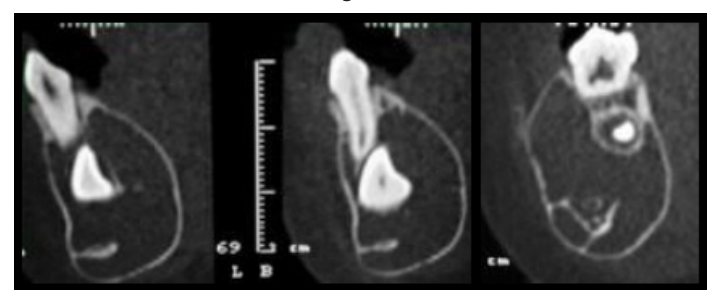

Figure 3. Parasagittal and coronal reconstruction demonstrating the preservation of the mandibular canal and the dental germs involved in the altered region.

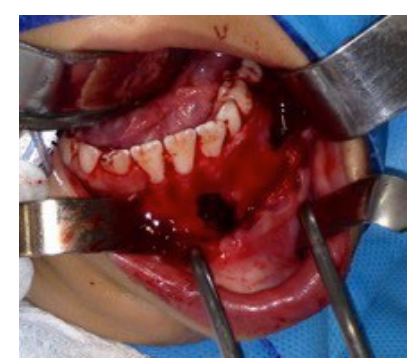

Figure 4. Image of exploratory surgery with the aim of diagnosis. The presence of an empty cavity was noted.

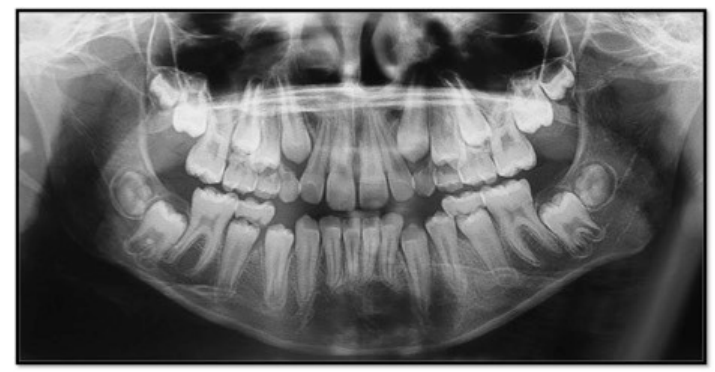

Figure 5. Panoramic $x$-ray 3 years later, showing the repair of the area affected by the lesion and the permanence of the teeth that were involved in the alteration.

\section{DISCUSSION}

SBC, described for the first time in 1929 by Lucas et al. ${ }^{6}$, is a pathology that usually afflicts long bones such as the femur ${ }^{1,3}$, however, in the maxillary bones there is a rate of incidence of $1.25 \%{ }^{4}$. In the oral cavity, the literature has shown the mandible to be the bone most affected. As for the age group affected by this entity, the vast majority of studies have reported an age range between 15 and $20^{7-9}$. In the quest to find other studies reporting SBC in children, as in the present case, only one report was found for the same age group, associated with a previous trauma ${ }^{10}$. Other SBC studies in children relate to children 10 years of age, or older ${ }^{7,9}$.

The majority of SBC cases are discovered by means of panoramic $x$-rays, as the lesion is asymptomatic ${ }^{1-5}$. As yet, there are no completely plausible theories to explain its etiopathogenesis. The literature has most commonly accepted the hypothesis that the trauma in the altered region results in the formation of a hematoma which, unable to repair itself, instead liquefies ${ }^{11}$. Although this theory has been fairly well disseminated, the patient in this report did not present any history of trauma in the region of the alteration, similar to other reports ${ }^{12}$. Other reported theories relating to SBC development include cystic degeneration of fibro-osseous lesions, vascular anomalies and altered bone metabolism ${ }^{11-12}$. 
In terms of the clinical and radiographic aspects, SBC shares a differential diagnosis mainly with the keratocystic odontogenic tumor (KOT) as both lesions have a benign character represented by growth, evolution and absence of symptoms. Another characteristic of SBC is the pattern of growth in the anterior-posterior direction, without expansion of the buccal and lingual cortices, similar to KOT. According to the authors, the absence of growth is observed in $92 \%$ of cases of $\mathrm{SBC}^{8}$. Moreover, the ornate appearance, contouring the vital teeth in the region of the alteration, leads to two diagnostic hypotheses. In the present case, given the multilocular nature and cortical expansion of the alteration, the following diagnostic hypotheses were raised: central giant-cell lesions, KOT, multicystic ameloblastoma or intraosseous vascular malformations, in addition to SBC. This was yet another motive for us to report on this clinical case. Few studies have described the variations of SBC's clinical presentation ${ }^{10,13}$.

When retrospective SBC studies or case studies are analyzed, it has been seen that the prognosis is very favorable ${ }^{12}$. Authors have advocated exploratory surgery as the approach for concluding the diagnosis and managing the case through monitoring. In one study, conducted in 2000, 10 cases of SBC were clinically and radiographically monitored over a period of 2 to 7 years. As far as the evolution of the lesions is concerned, 2 cases exhibited an increase in size over time, 1 case remained static, 6 cases presented a remodeling and just one was fully resolved. Based on the study, the authors suggested that a followup of asymptomatic and very likely cases of SBC should be carried out first after 2 months, and thereafter at 3 , 6 and 12 months $^{5}$. Other authors have also emphasized the success of the non-intervention appraoch ${ }^{14}$. Meanwhile some authors consider the clinical and radiographic aspects paramount in establishing an SBC diagnosis ${ }^{15}$.

Despite the conservative approach found in the literature, some larger and expansive, clinical cases of SBC,

\section{REFERENCES}

1. Barnes L, Eveson JW, Reichart P, Sidransky D (Eds.). World health organization classification of tumours. Pathology and genetics of head and neck tumours. p.327. Lyon: WHO Press; 2005.

2. Paiva LCA, Menezes FS, Porto GG, Cerqueira PRF. Simple bone cyst: case report. Rev Cir Traumatol Buco-Maxilo-Fac. 2011;11(2):15-22.

3. Teixeira RG, Bueno CES, Höfling RTB, Bussadori SK. Cisto ósseo simples. RGO, Rev Gaúcha Odontol. 2003;51(4):243-48. as in the present study, need confirmation of the diagnosis through exploratory surgery ${ }^{10,13}$. The need for this is justified by the clinical similarity to KOT, which presents with the behavior of a locally aggressive lesion with a high potential for recurrence. Moreover, in the present case, the child's parents were particularly anxious and distressed by their ignorance of the bone alteration. In addition to KOT, other lesions could come into the differential diagnosis of SBC, such as vascular malformations and central giant-cell lesions, principally.

Exploratory surgery to confirm the diagnosis of SBC has shown itself to be a good prognosis over time ${ }^{4}$, as in the present report. It must be stressed that the intervention proposed here was conservative, with no complications and the permanent tooth germs were preserved, as observed in the 3-year control, which monitors the image of the complete bone remodeling of the area initially affected.

\section{CONCLUSION}

To conclude, asymptomatic, radiolucent lesions that suggest a presumptive diagnosis indicative of SBC, may be clinically and radiographically monitored and the follow-up should be carried out in a short interval of time in the first few months and, if it is found to be static, increase the control interval, as suggested by Damante et al., $2000^{5}$. Nevertheless, atypical cases such as the present clinical case require confirmation of the diagnosis, which is carried out via exploratory surgery. The establishment of the diagnosis makes the handling of the case safer for both professional and patient.

\section{Collaborators}

All authors participated in the writing of the article and clinical follow-up of the case.

4. Andrade LE, Cerqueira LS, Rebouças DS, Marchionni AMT. Simple boné cyst: a case report. Rev Cir Traumatol Buco-MaxiloFac. 2016;16(2):36-39.

5. Damante JH, Da S Guerra EN, Ferreira Jr O. Spontaneous resolution of simple bone cysts. Dentomaxillofac Radiol. 2002 May;31(3):182-6. doi: 10.1038/sj/dmfr/4600696

6. Lucas CD. Do all cysts of the jaw originate from the dental system? J Am Dental Assoc. 1929;16:647. doi: 10.14219/jada. archive.1929.0086 
7. Discacciati ED, de Faria VM, Garcia NG, Sakai VT, Pereira AA, Hanemann JA. Idiopathic bone cavity: case series involving children and adolescents. J Investig Clin Dent. 2012;3(2):103-8. doi: 10.1111/j.2041-1626.2011.0087.x

8. Martins-Filho PR, Santos Tde S, Araújo VL, Santos JS, Andrade ES, Silva LC. Traumatic bone cyst of the mandible: a review of 26 cases. Braz J Otorhinolaryngol. 2012;78(2):16-21. doi: 10.1590/ S1808-86942012000200004

9. An SY, Lee JS, Benavides E, Aminlari A, McDonald NJ, Edwards $P C$, et al. Multiple simple bone cysts of the jaws: review of the literature and report of three cases. Oral Surg Oral Med Oral Pathol Oral Radiol. 2014;117(6):e458-69. doi: 10.1016/j. oooo.2014.03.004

10. Shigematsu H, Fujita K, Watanabe K. Atypical simple bone cyst of the mandible. A case report. Int J Oral Maxillofac Surg. 1994;23(5):298-9.

11. Harnet JC, Lombardi T, Klewansky P, Rieger J, Tempe MH, Clavert JM. Solitary bone cyst of the jaws: a review of the etiopathogenic hypotheses. J Oral Maxillofac Surg. 2008;66(11):2345-8. doi: 10.1016/j.joms.2007.08.035
12. Madiraju G, Yallamraju S, Rajendran V, SrinivasaRao K. Solitary bone cyst of the mandible: a case report and brief review of literature. BMJ Case Rep. 2014;30: doi:10.1136/bcr-2013200945.

13. Tong AC, Ng IO, Yan BS. Variations in clinical presentations of the simple bone cyst: report of cases. J Oral Maxillofac Surg. 2003;61(12):1487-91. doi: 10.1016/j.joms.2003.05.003

14. Blum T. An additional report on traumatic bone cysts; also a discussion of Dr. John G. Whinery's paper, "Progressive Bone Cavities of the Mandible". Oral Surg Oral Med Oral Pathol. 1955 Sep;8(9):917-39.

15. Szerlip L. Traumatic bone cysts. Resolution without surgery. Oral Surg Oral Med Oral Pathol. 1966 Feb;21(2):201-4.

Received on: 17/8/2016

Final version resubmitted on: 11/10/2016

Approved on: 16/12/2016 